\title{
GEOGRAFIAS, IMAGENS E LITERATURA: DIÁLOGOS POSSÍVEIS
}

\author{
Geographies, images and literature: possible dialogues \\ Geografías, imágenes y literatura: diálogos posibles
}

\section{Cláudio Benito Ferraz}

Doutor em Geografia Humana pela Universidade de São Paulo (USP), Professor do Departamento de Educação da UNESP/Campus de Presidente Prudente. UNESP/Campus de Presidente Prudente. Rua Roberto Simonsen, 305. Jardim das Rosas - Presidente Prudente - SP. CEP 19060-900.

E.mail:cbenito2@yahoo.com.br

\section{Eguimar Felício Chaveiro}

Doutor em Geografia Humana pela Universidade de São Paulo (USP). Professor do Programa de PósGraduação em Geografia do IESA/UFG. Universidade Federal de Goiás (UFG). Instituto de Estudos Sócio-Ambientais (IESA). Campus Samamabaia. Av. Esperança s/n. Goiânia - GO. CEP 74.690-900. E.mail:eguimar@hotmail.com

\section{Flaviana Gasparotti Nunes}

Doutora em Geografia pela UNESP/Presidente Prudente. Professora do Programa de Pós-Graduação em Geografia da UFGD. Coordenadora da Rede Internacional de Pesquisa Imagens, geografias e educação. Universidade Federal da Grande Dourados (UFGD). Faculdade de Ciências Humanas .Rod. Dourados-Itahum, Km 12. Cidade Universitária - Dourados - MS. CEP 79804-970.

E.mail: flaviana.nunes@hotmail.com

\section{Julio Cesar Suzuki}

Doutor em Geografia Humana pela Universidade de São Paulo (USP). Professor do Departamento de Geografia da Universidade de São Paulo (USP). Universidade de São Paulo (USP). FFLCH Departamento de Geografia. Av. Prof. Lineu Prestes, 338. Cidade Universitária - São Paulo - SP. CEP 05508-000

E.mail:jcsuzuki@usp.br

\section{RESUMO}

Este artigo visa apresentar as análises dos coordenadores do Grupo de Trabalho "Geografias, imagens e literatura: interlocuções possíveis" que ocorreu no interior do XI ENANPEGE, realizado na cidade de Presidente Prudente (SP) em outubro de 2015. O texto discorre, por meio de tabelas, a sistematização das principais aspectos que se destacaram do conjunto de vinte trabalhos aprovados, desde suas linhas temáticas, as linguagens artísticas que abordaram, os referenciais teóricos e metodológicos, as concepções de geografia e os centros de origem das pesquisas; no final desenvolvemos análises a partir dos elementos teóricos e políticos que se relacionam com a questão da linguagem científica da Geografia no encontro com as linguagens artísticas das literaturas e das imagens, de maneira a melhor pontuar o atual estado de desenvolvimento desses estudos, seus limites e possibilidades para o futuro da ampliação das pesquisas em Geografia.

Palavras chave: Geografias; Literaturas; Imagens; Linguagens. 


\begin{abstract}
This article presents the analyzes of the Working Group coordinators "Geographies, images and literature: possible dialogue" held within the XI ENANPEGE, in the city of Presidente Prudente (SP) in October 2015. The text shows through tables, the systematization of the main aspects that stood out in the group of twenty works approved, such as its thematic lines, the artistic languages that addressed the theoretical and methodological benchmarks, the concepts of geography and the centers of origin of research. At the end, we developed analyzes from the theoretical and political elements that relate to the issue of scientific geography language in the meeting with the artistic languages of literature and images, so the best way to measure the current development status of these studies, its limits and possibilities for the expansion of research in Geography.
\end{abstract}

Keywords: Geographies; Literary; Images; Languages.

\title{
RESUMEN
}

Este artículo pretende presentar los análisis de los coordinadores del Grupo de Trabajo "Geografías, imágenes y literatura: interlocuciones posibles", que ocurrió en el interior del XI ENANPEGE, realizado en la ciudad de Presidente Prudente (SP) en octubre de 2015. El texto presenta, a través de tablas, la sistematización de los principales aspectos que se destacaron en el conjunto de los veinte trabajos aprobados, tales como sus líneas temáticas, los lenguajes artísticos que abordaron, los marcos teóricos y metodológicos, los conceptos de Geografía y los centros de origen de las investigaciones. Al final, desarrollamos algunos análisis a partir de los elementos teóricos y políticos que se relacionan con la cuestión del lenguaje científico de la Geografía en el encuentro con los lenguajes artísticos de las literaturas y de las imágenes, de manera que mejor se destacara el actual estado de desarrollo de estos estudios, sus límites y posibilidades para la ampliación de las investigaciones en Geografía.

Palabras clave: Geografías; Literaturas; Imágenes; lenguajes.

\section{INTRODUÇÃO}

Este artigo é uma produção coletiva resultante das apresentações e debates ocorridos no Grupo de Trabalho “Geografias, Imagens e Literatura: Interlocuções Possíveis” que desenvolveu suas atividades no interior do XI ENANPEGE, realizado nos dias 9 a 12 de outubro de 2015 na cidade de Presidente Prudente (SP).

Esse Grupo de Trabalho se efetivou a partir da união de dois conjuntos de pesquisadores com preocupações que se articulam às novas perspectivas para a linguagem científica da Geografia, notadamente a partir do encontro com as linguagens artísticas. De um lado, o conjunto de pesquisadores vinculados ao Grupo de Pesquisa Geografia, Literatura e 
Arte (GEOLITERART -http://dgp.cnpq.br/dgp/espelhogrupo/6190421227717733) que já organizara o Grupo de Trabalho Geografia e Literatura: Interlocuções Possíveisdesde o IX ENANPEGE (Goiânia, 2011), assim como o Simpósio Internacional de Geografia, Literatura e Arte.

Por outro lado, por pesquisadores da Rede Imagens, Geografias e Educação(www. geoimagens.net), composta pelos seguintes Grupos de Pesquisa: Linguagens Geográficas, http://dgp.cnpq.br/dgp/espelhogrupo/1672330247771967), (Geo)grafias, Linguagens e Percursos Educativos, (http://dgp.cnpq.br/dgp/espelhogrupo/7618784349537022) e POIESIS (Política Espacial das Imagens Cartográficas (http://dgp.cnpq.br/dgp/ espelhogrupo/7117286740257357), entre outros grupos de pesquisadores brasileiros e estrangeiros que organizam o Colóquio Internacional "A Educação pelas imagens e suas geografias.

Em decorrência das experiências de trabalho efetivadas por esses pesquisadores com as linguagens imagéticas (cinema, fotografia, desenhos e cartografias pós-representacionais) e literárias (romances, contos, novelas e poesias), tornou-se pertinente estabelecer uma instância para possibilitar trocas e análises, tanto metodológicas quanto de referenciais teóricos, de maneira a traçar aproximações e distinções necessárias ao mútuo crescimento intelectual e temático dos pesquisadores reunidos nesse GT, assim como da linguagem geográfica como um todo.

As pesquisas apresentadas e debatidas apontam outras possibilidades de produção de significados para os estudos científicos da Geografia, notadamente os relacionados com novas perspectivas para os conceitos estruturadores da lógica espacial da sociedade (lugar, paisagem, território, região, escala, fronteira e espaço) e de como esses conceitos podem reverberar em novos entendimentos dessas linguagens artísticas a se desdobrarem na criação científica enquanto ações de ensino e pesquisa geográficas.

A seguir, apresentaremos um painel geral dos elementos que identificamos mais presentes no conjunto das pesquisas apresentadas, tentando traçar uma cartografia do GT, das suas possibilidades futuras, assim como de aspectos que delineiam distanciamentos e trocas entre as perspectivas teóricas e temáticas debatidas. 


\section{CARTOGRAFIA DOS TRABALHOSAPROVADOS}

A partir dos 20 trabalhos aprovados" para compor o Grupo de Trabalho "Geografias, Imagens e Literatura: interlocuções possíveis", a coordenação do GT passou a analisar o conjunto de textos. Essa análise se desdobrou na elaboração de uma sequência de tabelas que pontuam os principais aspectos pela coordenação levantados. Os dados presentes nessas tabelas expressam a cartografia das pesquisas que envolvem o encontro da linguagem científica da Geografia com as linguagens artísticas imagéticas e literárias.

Os dados não visam esgotar a questão, mas tão somente esboçar os parâmetros que permitem estabelecer a territorialidade dos debates e referenciais balizadores das pesquisas, apontando as potencialidades futuras, assim como os limites para com a criação de novas perspectivas para o pensamento geográfico a partir do encontro com a força estética presente nos processos criativos artísticos das imagens e literários.

Os vinte trabalhos aprovados foram classificados em duas linhas temáticas de pesquisas (Tabela I).Essas duas linhas foram desdobradas em linguagens pesquisadas: artísticas literárias (Tabela II) e linguagens imagéticas (Tabela III). Optamos em empregar o termo "linguagem" para as especificidades que se desdobram dessas duas linhas pelo fato de tentarmos manter um referencial comum em relação a diversidade temática das pesquisas, por assim entendermos que essas especificidades são detalhamentos das respectivas linguagens (literária e imagética). Diante disso, optamos em subdividir as mesmas em tipos mais específicos de linguagens, pois o romance, por exemplo,possui uma forma singular de organizar as palavras no processo de criação de seu campo estético, diferente da poesia, etc.; o mesmo ocorre em relação ao campoda fotografia, por exemplo, que possui um "alfabeto" próprio no processo estético de criar suas obras imagéticas, diferente do cinema, etc. O comum a esses distintos campos linguísticos é que todos visam comunicar algo, desejam estabelecer um desafio de sentido ao que se tem consolidado no que tange ao conhecimento geográfico a partir do encontro com o leitor/observador das obras e artistas focados.

TABELA I - LINHAS DE PESQUISA

\begin{tabular}{c|c} 
Linhas & Total de Trabalhos \\
\hline Imagem & 8 \\
\hline Literatura & 12 \\
\hline
\end{tabular}

Fonte: Trabalhos aprovados para o GT Geografias, Imagens e Literatura: interlocuções possíveis

Os trabalhos aprovados podem ser acessados em http://www.enanpege.ggf.br/2015/anais/. 
Dos 20 trabalhos aprovados, a maior parte focou a linguagem literária (12trabalhos). Um aspecto que pode explicar tal prioridade talvez seja que dos grupos de pesquisa envolvidos na coordenação do GT, dois deles desenvolvem há mais tempo pesquisas que abordam principalmente a literatura. $\mathrm{O}$ aspecto principal é que a grande maioria desses trabalhos, seja eles de mestrado ou de doutorado, foca uma obra em específico, variando apenas o tipo de literatura (romance, conto, poesia). Contudo, apesar do número bem menor, dois trabalhos não focaram uma obra em específico, mas o conjunto de escritos de determinado autor, daí colocarmos na tabela II o item "escritores".

Apesar de não aparecer nos dados presentes na tabela, o foco dos escritos apresenta um corte espacial bem claro. De um lado, identificamos pesquisas sobre obras de caráter canônico da literatura nacional (6 obras/autores como O quinze, Vidas Secas, Jorge Amado, Mário de Andrade etc.), priorizando a literatura que aborda o nordeste brasileiro, focando aí sua paisagem, ou a modernização urbana do país, realçando os processos de desterritorialização dos referenciais tradicionais da vida.

Por outro lado, identificamos um conjunto de trabalhos que abordam livros/autores de caráter mais local, ou seja, mais próximos aos centros de pesquisas de origem dos trabalhos. São obras e autores reconhecidos numa extensão espacial mais restrita, não facilmente lembrados quando a escala espacial se refere a extensão nacional (6 trabalhos se caracterizam nesse grupo, abordando obras de Lobivar Matos, Gilberto de Mendonça Telles, Jesus Barros Boquady, etc.).O foco principal dessas pesquisas se atém ao aspecto de expressar a importância desses autores/obras para a formação de uma identidade territorial que caracterize a forma espacial daquela região ou cidade.

TABELA II - LINGUAGENS LITERÁRIAS PESQUISADAS

Linguagens

\begin{tabular}{cl} 
Romances/Contos & 5 \\
\hline Poesia & 5 \\
\hline Escritores & 2 \\
\hline
\end{tabular}

Fonte: Trabalhos aprovados para o GT Geografias, Imagens e Literatura: interlocuções possíveis

Os trabalhos voltados à abordagemdas imagens apresentam uma variação maior de linguagens pesquisadas, destacando o cinema e fotografia em maior número, mas também sobre a linguagem cartográfica, sobre a pintura e um sobre imagens presentes na rede mundial de computadores. Com uma variedade maior de linguagens e um número menor de trabalhos ao todo, em relação aos voltados para as literaturas, esse grupo se caracteriza 
pelo aspecto transfronteiriço das obras abordadas (fotografias de Moçambique, filmes de Charles Chaplin, pintura do uruguaio Torres Garcia, a questão cartográfica da fronteira Brasil/Paraguai etc.).

Uma explicação para o número menor de trabalhos sobre a imagem e Geografia, relaciona-se ao fato de que dois grupos de pesquisa que organizaram o GT são vinculados a Programas de Pós-Graduação mais recentes (UFES e UFGD), sendo esses dois grupos que focam a questão da imagem, ao contrário dos outros dois grupos de pesquisa, vinculados a Programas de Pós-Graduação mais tradicionais (UFG e USP), os quais priorizam a questão da literatura. No entanto, a grande variedade de linguagens imagéticas abordadas aponta para a pertinência e a forte potencialidade dessa linha de pesquisa para o futuro de estudos geográficos sobre imagem.

TABELA III - LINGUAGENS IMAGÉTICAS PESQUISADAS

\begin{tabular}{c|c} 
Linguagens & Quantidade \\
Cinema & 3 \\
\hline Fotografias & 2 \\
\hline Cartografias & 1 \\
\hline Pinturas/Desenhos & 1 \\
\hline Outros & 1 \\
\hline
\end{tabular}

Fonte: Trabalhos aprovados para o GT Geografias, Imagens e Literatura: interlocuções possíveis

Quanto aos centros de pesquisa originários dos trabalhos selecionados, temos uma diferença clara quando comparamos os estudos que abordam a linguagem das literaturas (Tabela IV) e os que se debruçam sobre as linguagens imagéticas (Tabela V).

Confirmando o já apontando anteriormente, a maior tradição dos grupos de pesquisa vinculados aos Programas de Pós-graduação da USP e UFG, pode explicar a sensível distância entre o número de trabalhossobre a linguagem literária (somam 7 ao todo) provenientes desses dois centros em relação aos demais cinco centros de pesquisa (que somam 5 trabalhos de literatura ao todo).

O que diferencia o foco entre esses dois principais centros de pesquisas abordandoGeografia e literatura é que a USP prioriza autores e obras do cânone nacional, notadamente obras que focam o Nordeste e outras regiões do país, enquanto a UFG se volta mais para autores de expressão local, sendo que boa parte aborda a cidade de Goiânia. 
TABELA IV - CENTROS DE PESQUISAS DOS TRABALHOS SOBRE LITERATURAS

\begin{tabular}{c|c} 
Locais de Pesquisa & Quantidade de Pesquisas \\
UFG (Goiás) & 4 \\
\hline USP (São Paulo) & 1 \\
\hline UFGD (Mato Grosso do Sul) & 1 \\
\hline UFES (Vitória) & 1 \\
\hline UFRRJ (Rio de Janeiro) & 1 \\
\hline UECE (Ceará) & 1 \\
\hline UNIOESTE (Paraná)
\end{tabular}

Fonte: Trabalhos aprovados para o GT Geografias, Imagens e Literatura: interlocuções possíveis

Os trabalhos que se voltam para as linguagens imagéticas apresentam maior distribuição entre os vários centros de pesquisa, com exceção da USP que não compareceu com trabalhos voltados à essa linguagem. A necessidade de ampliar o número de pesquisas sobre imagens e Geografia fica evidente na comparação entre as tabelas IV e V, principalmente pela maior variedade de linguagens imagéticas envolvidas (cinema, fotografia, pinturas, cartografias etc.), assim como pelo equilíbrio entre os diversos centros, não havendo concentração de tipos de pesquisa em determinada instituição (como ocorre com os trabalhos voltados à literatura), potencializando, assim, a força democrática da dinâmica espacial dos estudos entre Geografia e imagens

TABELA V - CENTROS DE PESQUISAS DOS TRABALHOS SOBRE IMAGENS

\begin{tabular}{c|c} 
Locais de Pesquisa & Quantidade de Pesquisas \\
\hline UFG (Goiás) & 2 \\
\hline UFGD (Mato Grosso do Sul) & 2 \\
\hline UFF (Rio de Janeiro) & 1 \\
\hline UERJ (Rio de Janeiro) & 1 \\
\hline PUC (Rio de Janeiro)
\end{tabular}

Fonte: Trabalhos aprovados para o GT Geografias, Imagens e Literatura: interlocuções possíveis

A tabela VI foi elaborada após uma série de debates sobre como os trabalhos abordavam as linguagens artísticas. O que pretendiam com os estudos geográficos sobre literaturas e imagens? Essa pergunta norteou as análises feitas em conjunto, mas o resultado não foi fácil, pois se os autores explicitavam em seus textos determinado objetivo, conforme 
desenvolviam suas análises, muitas vezes acabavam apontando outras intenções, mais implícitas e nem sempre por eles identificadas em suas conclusões.

A trama entre o título, a introdução, o desenvolvimento metodológico, as citações e a bibliografia explicitamente empregada apontou um texto subliminar, o qual optamos por destacar como o articulador das intenções de cada trabalho. Esse articulador de intenções permitiu estabelecer um padrão comum passível de agrupar em três grupos de abordagem das linguagens artísticas.

TABELA VI - PERSPECTIVAS DAS PESQUISAS

\begin{tabular}{c|c} 
Perspectiva Principal & Quantidade de Trabalhos \\
\hline Identificar Geografia na Obra artística & 9 \\
\hline Arte auxiliando conceitos geográficos & 8 \\
\hline Criar nos encontros de linguagens & 3 \\
\hline
\end{tabular}

Fonte: Trabalhos aprovados para o GT Geografias, Imagens e Literatura: interlocuções possíveis

Dos 20 trabalhos aprovados para o GT, quase metade (9) explicitava o desejo de identificar a Geografia nas obras artísticas, principalmente nos romances e nos filmes. Tal compreensãopode se constituir num limite para os estudos, pois restringe a força artística de uma obra a ser o confirmador de uma concepção de Geografia já estabelecida. Neste sentido, apontou-se, durante os debates, a necessidade de que esses estudosprovoquem rasuras nos esquemas da Geografia, ou seja, de que avancem na perspectiva de rasurar os sentidos já consagrados do que se institucionalizou como geográfico, ao invés de aplicarem um conhecimento já fixado do que vem a ser Geografia sobre uma obra, buscando nela a identificação dos elementos a priori denominados como geográficos, principalmente em seu aspecto paisagístico (formação do relevo, tipos de vegetação, processos urbanos etc.)

Um outro conjunto significativo de trabalhos (8) busca avançar nesse sentido, ou seja, ir além desse processo de identificação de uma Geografia já dada ao se estudar uma obra. Esses trabalhos se concentram mais nas abordagens sobre determinadas obras poéticas, nas aproximações com as linguagens da fotografia e da pintura, o que permite aludir para a força de escape a clichês estéticos que a poesia possui em relação a muitos estudos sobre romances, assim como da fotografia em relação ao cinema, mas isso com certeza é um desafio a ser abordado em novas pesquisas e encontros futuros.

Esses estudos objetivam buscar nas artes elementos que permitem auxiliar no funcionamento de conceitos e pertinentes à análise geográfica (paisagem, lugar, território, dinâmica e mobilidade espacial, Estado-Nação etc.), propiciando abordagens mais focadas 
na subjetividade perceptiva e na sensibilidade estética para provocar análises científicas, desfocando os aspectos mais analíticos ou lógico-racionalizantes. Contudo, um debate se instaurou no interior da coordenação do GT sobre essa perspectiva. Se por um aspecto ela é um avanço em relação a como a ciência, em especial o discurso científico da Geografia, entende o encontro com as linguagens artísticas, por outro aspecto, foi percebido em alguns trabalhos que o trabalho com a linguagem artística pode se restringir a reprodução de clichês de sensibilidade na construção dos discursos científicos.

São trabalhos interessantes, mas correm o risco de simplificar a força estética das obras artísticas, tornando-as objetos para sujeitos pensantes que priorizam a pura sensação, o que pode desembocar numa supervalorização da subjetividade, limitando o discurso científico da Geografia a um relativismo de sensações subjetivas, ficando preso a um jogo de palavras em que a forma poética de sua escrita pode camuflar o vazio de conteúdo das análises presentes. Essa é uma observação crítica fundamental que devemos ter para analisar e avaliar os trabalhos em futuros encontros desse GT.

Já um grupo pequeno de trabalhos (3 ao todo) tenta identificar no encontro com as linguagens artísticas a força criativa de pensamentos, ou seja, no encontro das linguagens se dá o local do acontecimento de pensamentos e imagens espaciais que permitam rasurar o já estabelecido como Geografia, assim como o já delimitado como literatura ou imagem artística. Esses três trabalhos possuem em comum a preocupação com a linguagem geográfica enquanto encontro na escola, no nível do ensino (básico ou superior), mas não visam entender esse encontro com o ensinocomo produção de recursos didáticos e/ ou de meios para facilitar o trabalho em sala de aula, mas sim como construção de novas perspectivas epistemológicas e ontológicas para a Geografia.

São trabalhos, portanto, que buscam traçar novas perspectivas para o pensamento geográfico a partir da escola como instância produtora de conhecimento, não reduzindo a instituição de ensino a ser mera reprodutora de saberes já estabelecidos por outras instâncias e especialistas. Contudo, são trabalhos mais experimentais e ainda balbuciantes em suas intenções, apesar de explicitarem o desejo de serem referenciais metodológicos passíveis de generalização, ficando mais no nível das intenções do que de proposições. A possibilidade de aprofundar e ir além de seus desejos e intenções cobra a necessidade da continuidade de encontros e espaços de discussão como o do GT em questão.

A grande riqueza desse mapa das perspectivas de pesquisas sobre Geografia, literatura e imagens é a necessidade de ampliar e aprofundar essas diferentes linhas de abordagens, pois não se pode crer que exista apenas um caminho a ser percorrido no encontro entre Geografia e linguagens artísticas, mas que a troca e tensões advindas dessas várias formas 
de experimentações e estudos é que possibilita o enriquecimento dessa temática para os estudos geográficos.

TABELA VII - REFERENCIAL TEÓRICO DESTACADONA PESQUISA

\begin{tabular}{c|c} 
Referencial mais presente & Quantidade de Trabalhos \\
Fenomenologia & 11 \\
\hline Estudos Pós-Coloniais ou Culturais-Marxistas & 6 \\
\hline Filosofia da Diferença & 3 \\
\hline
\end{tabular}

Fonte: Trabalhos aprovados para o GT Geografias, Imagens e Literatura: interlocuções possíveis

Quanto aos referenciais teóricos (Tabela VII), identificamos uma forte presença, mesmo que não explicitada nos textos, da perspectiva fenomenológica. Tal identificação se tornou possível considerando-sea bibliografia citada, assim como os objetivos propostos e os mecanismos analíticos adotados, tanto nas pesquisas voltadas para abordar as linguagens literárias quanto as imagéticas.Esses elementos analíticos destacados denotam a clara intenção de buscar soluções objetivas para os entraves do discurso científico da Geografia a partir dos elementos subjetivos e sensoriais identificados na produção artística.

O mesmo se deu em relação aos estudos que, apesar de se voltarem ao entendimento das linguagens artísticas como elementos da sensibilidade e da apreensão subjetiva das formas e processos, não se enquadravam de maneira mais convincente em abordagens fenomenológicas, tanto por terem um vínculo com citações e referenciais a partir da perspectiva dos novos estudos marxistas, assim como por apresentarem preocupações e abordagens que se desdobram dessa perspectiva e se aproximam mais dos estudos culturais ou pós-coloniais. Diante disso, optamos em criar essa alternativa generalizante e genérica de um conjunto de trabalhos que delineiam perspectivas em que se mesclam esses referenciais(novos estudos culturais, pós-coloniais e neo-marxistas), apesar de muitos de seus autores não terem assim explicitado.

O último grupo de trabalhos, bem reduzido, enquadramos na perspectiva da filosofia da diferença. O motivo desse enquadramento se dá em função de seus autores assim terem explicitado em seus textos, fazendo referências a autores classificados dessa forma classificados (Felix Guattari, Gilles Deleuze, Silvio Gallo, entre outros) e buscando, através de seus objetivos e narrativas, caminhos que reverberam as intenções apontadas por essa perspectiva filosófica. Contudo, apesar de assim se assumirem, esses textos apresentam paradoxos e desviosteóricos, muitas vezes afirmando posturas que não coadunam com essa linha ou plano de referencial, tendendo a reproduzirconceitos que se colocam como fixos 
em uma identidade, servindo mais para ilustrar a argumentação ao invés de se abrirem para o movimento do pensamento, para além do entendimento de aplicar uma metodologia de análise na solução de um determinado problema.

TABELA VIII - CONCEPÇÃO DE GEOGRAFIA DESTACADANA PESQUISA

\begin{tabular}{c|c} 
Referência mais presente & Quantidade de Trabalhos \\
Geografia Cultural & 14 \\
\hline Doreen Massey & 3 \\
\hline Geografia Neomarxista & 3 \\
\hline
\end{tabular}

Fonte: Trabalhos aprovados para o GT Geografias, Imagens e Literatura: interlocuções possíveis

A concepção de Geografia mais presente em cada trabalho selecionado foi fruto de debates e análises, tanto pelo fato de não estar explicitamente declarada na redação dos mesmos, quanto pela maneira híbrida com que boa parte dos trabalhos fazia referência a autores de diferentes linhas e perspectivas, sem uma devida análise dessas distinções.

Diante disso, optamos por reproduzir a mesma metodologia aplicada na sistematização presente nas tabelas anteriores: comparamos os objetivos, as citações presentes ao longo do texto, a forma de desenvolver a metodologia e conclusão dos estudos para assim identificarmos uma perspectiva mais forte capaz de estabelecer vínculos entre uma intenção de estudos e uma dada concepção de Geografia que ali se tornava mais pertinente.

Com isso, identificamos que a grande maioria de trabalhos (14) se aproxima mais do que atualmente se denomina como Geografia Cultural ou Humanista, apesar de neles estarem presentes referências que iam de Milton Santos a Rogério Haesbaert. São trabalhos que buscam inovar metodologicamente os estudos geográficos num contexto de concepção de ciência como instância acadêmica e que visam solucionar os problemas e entraves do discurso científico consolidado.

Um segundo grupo de trabalhos (3) foi classificado, tanto a partir de citações presentes nos textos quanto pelo desenvolvimento de suas argumentações, assim como por assumirem explicitamente a perspectiva de análise da Geografia a partir dos referenciais de DoreenMassey. Esse pequeno grupo se aproxima mais das abordagens deleuzianas, mas encontra dificuldades quanto a expressar uma nova linha de leitura geográfica que deriva das práticas institucionalizadas sem colocar-se como mero antagonismo aos parâmetros acadêmicos instituídos, ou seja, não reduzindo a forma de fazer/pensar o discurso científico como uma alternativa dualista e redentora das práticas científicas atualmente entendidas comomajoritárias e institucionalizadas no interior dos centros de pesquisas e práticas escolares. 
Um terceiro grupo, também pequeno (3 trabalhos), foi por nós classificado como mais próximo do que podemos chamar de Geografia neo-marxista. Assim o denominamos pelo fato de seus autores terem preocupações e fazerem referências a autores de tradição marxista (Ruy Moreira, Carlos W. P. Gonçalves, DavidHarvey etc.), mas buscando abordar os elementos culturais e artísticos por uma leitura que não mais os delimita a esfera da superestrutura ideológica, mas como componentes da produção material da sociedade capitalista atual, apresentando forças críticas e questionadores da ordem ideológica. Da mesma forma que os estudos voltadosà perspectiva da Geografia Cultural, com os quais acabam se confundindo em vários momentos devido a citações e referências a ideias presentes nessa abordagem dita humanista, também objetivam solucionar os problemas enfrentados pelo referencial científico dominante, não buscando outros sentidos de ciência, mas modificando-apor meioda inovação metodológicapara assim buscarem solucionar os problemas e limites da prática científica instaurada.

Pontuamos, assim, a cartografia dos trabalhos selecionados para o GT, aqui abordados de forma generalizante, visando apenas estabelecer uma leitura das principais características da diversidade de questões levantadas, assim como de perspectivas futuras necessárias para maior aprofundamento dessas problemáticas e caminhos teóricos e temáticos, de maneira a propiciar a ampliação de pesquisas sobre essas perspectivas na Geografia.Diante do que foi assim classificado, pontuaremos, a seguir, alguns aspectos sobre esse conjunto de trabalhos a partir dos elementos que focaram: a palavra e a imagem.

\section{CÍRCULOS DE DIÁLOGOS: A DIMENSÃO POLÍTICA DA PALAVRA/IMAGEM}

A complexidade do espaço contemporâneo instituído pela arquitetura das redes moduláveis, e o que se tem denominado "sociabilidade envenenada" (PELBART, 2008); os dispositivos econômicos globais que criam novas diásporas de trabalhadores; a pressão sobre os ambientes por meio de ruídos; o impacto da torrente de informações na esfera da percepção, da cognição e nas representações sociais; a emergência do sujeito global que, a um só tempo, se fragmenta e vê aumentado a sua capacidade de comunicar e autodeterminar-se no que fala e pensa, a colocar em crise a ideia de sujeito individuado que, por um lado, subsume aos processos de sujeição social e, por outro, sucumbe em meio a servidão maquínica (LAZZARATO, 2014) dessa territorialidade sempre fugidia e metamorfoseante do capitalismo-mundo, exige, das ciências em geral - e do campo das humanidades - uma abertura para o diálogo, para o fora, para o impensado.

No caso específico da Geografia brasileira, o comando deletério das instituições de fomento e de avaliação no modo de pensar dos geógrafos, além de inclinar a produção para 
o campo pragmático do neopositivismo dissimulado (pois se pauta na ideia transcendente e metafísica da função essencial da pesquisa para fornecer soluções práticas para os ditos problemas espaciais a partir de uma espécie de "rigor mortis" do pensamento criativo), camufla com a boa intenção de seus pesquisadores o verdadeiro objetivo de suas práticas investigativas com os interesses estriadores do Estado-Nação/determinantes economicistas, o que reverbera, de maneira canhestra, na postura "séria" e "ordeira" dos que comungam desse repertório relacional e do micropoder dentro dos grupos (de pesquisa ou de relações profissionais), departamentos e demais esferas da estrutura acadêmica. A tendência é o adestramento das dizibilidades geográficas, ou a sua redução ao critério da normatividade: territorializam-se os processos de disciplinarização dos corpos (pensamentos e atitudes).

De maneira tênue e espraiada, alternativas, contra-linguagens e resistências têm surgido no campo da cartografia, da educação ambiental, das representações geográficas que teimam em criar, ousar, gerar espectro de vitalidade da palavra. Esse efeito de ranhura alivia o peso imperial de se trabalhar sob a vigilância institucional. E recoloca em cena a importância política do dizer. Os corpos desejantes por outros possíveis forçam os mecanismos de sujeição social a se desterritorializarem e instigam a busca por novos referenciais de localização e orientação do fazer ciência como obra de criação coletiva.

Nesse campo, o diálogo entre Geografia, literatura e imagem se abre como usina de possibilidades, a partir do qual o mimetismo insosso institucional pode dar lugar a efeitos políticos pela dimensão criativa e criadora. Contudo, isso não quer dizer abandonar as leituras clássicas, por exemplo, do pensamento crítico; ou se fechar num único campo discursivo. O que está em questão é a ampliação dos modos de ver, a abertura para a dúvida, a vontade de entrelaçamento e de aprendizagem; a consciência que a Geografia enquanto narrativa feita pelo ser humano - e mirada a ele - pode produzir potências de encontros.

Nesse momento, instaura-se um próprio repensar, ou seria melhor (des)pensar, o que se entende por "humano"; tal termo encerra um ideal de humanidade/humanismocaracterizado por uma generalização de sentidos e desejos, pois tudo que é de bom que pensamos sobre nós mesmosali se encontra fixado, mas esse "tudo" depende desse "humano" que tende a pensar sempre positivamente sobre si mesmo. Humano é uma palavra imensa, assim como seus correlatos humanismo e humanidade, imensidão que abarca tudo que esse humano deseja de si, de nossas melhores intenções, mas que nisso arrasta tudo que não queremos ser de nós mesmos (é humano o ódio, a inveja, a intriga, o assassínio, a violência, a destruição etc. etc. etc.). Tal generalização é a arrogância com que, com todas as boas intenções, esse humano, ou humanismo do homem se autoproclama como o único ser com tal poder de definir o certo e o errado de todas as coisas (a "coisa" é o indígena, que devemos proteger 
ou civilizar; a "coisa" pode ser uma rocha, a qual devemos racionalmente explorar já que é não tem vida, é um não ser; a “coisa”são os vegetais e demais animais, que por não serem humanos são irracionais etc.).

Só o humano sente, só o humano pensa, só o humano reina sobre tudo e todos. Grandes poderes, grandes responsabilidades. Afinal, uma rocha não faz arte, uma abelha não faz arquitetura, uma orquídea não sente a sua beleza estética. Mas como essas coisas instauram tanta beleza, tanta criação, tanto sentimentos e pensamentos? Como essas coisas conseguem se orientar e se localizar no espaço da vida sem necessariamente precisarem de nós humanos? Só aquilo que o homem sente e diz é que pode ser conhecimento válido? Não podemos aprender com as "coisas" não-humanas?

Mas a arte, essa criação humana, pode ser uma maneia de nós, humanos, sermos outra coisa, algo além do que idealizamos ser? Devir não humano no homem (DELEUZE; GUATTARI, 2010), um desafio e uma necessidade para sairmos dessa prisão a que nos apegamos, a prisão de sermos orgulhosos de nossa superioridade humana sobre tudo o que nos rodeia. Um espaço extensivo e hierarquicamente classificado, delimitado, regionalizado em suas funções, categorias e valores a partir de seu epicentro intelectual e sensitivo, o cérebro humano.

Mas como o animal não humano é capaz de provocar nesse cérebro humano novos sentires e pensamentos? Esse devir passou, certamente, pela arte da "metamorfose" em Kafka, mas outras obras literárias e imagéticas provocaram devires não-humanos no homem (A baleia Moby Dick de Melville; a tempestade de neve em um dos Sonhos no filme de Kurosawa; os quadrados e retângulos coloridos no quadrosBroadway Boogie Woogie de Mondrian, etc. ). Isso não quer dizer que não somos humanos, mas que o sentido de humanidade tem que ser colocado em devir-outro para podermos ter uma compreensão melhor do que somos no/com o mundo. É isso que a arte tem como sua grande potencialidade de nos fazer sentir, de instigar a pensarmos além do que entendemos ser o certo e o óbvio de nós mesmo e do mundo. Peguemos um exemplo, o poema "A Pedra", de Manoel de Barros.
Pedra sendo
Eu tenho gosto de jazer no chão.
Só privo com lagarto e borboletas.
Certas conchas se abrigam em mim.
De meus interstícios crescem musgos.
Passarinhos me usam para afiar seus bicos;
Às vezes uma garça me ocupa de dia.
Fico louvoso. 
Há outros privilégios de ser pedra:

a - Eu irrito o silêncio dos insetos.

b - Sou batido de luar nas solicitudes.

c - Tomo banho de orvalho de manhã.

d - E o sol me cumprimenta por primeiro (BARROS, 2005, p. 27).

Quantas imagens e sensações aí se desdobram! Não é que deixamos de sermos o agenciador dessas sensações e sentidos a partir das palavras do poema, mas é que essas carregam outros afectos e perceptos, que não se restringem ao que da pedra nos afeta, mas o que nas palavras/imagens do poemase potencializa em fuga do que pensamos ser uma pedra, do aspecto entendido como superior com o qual nosso intelecto logico-racionalista a reduz a um mero objeto inanimado, não orgânico, sem vida.

É inegável quea pedra pode ser definida como um seixo de rocha e, em decorrência de processos físico-químicos, dos movimentos de pressão, das forças exógenas etc., ela pode ser classificada em metamórfica, magmática ou sedimentar, mas ela é algo mais intenso que só sua forma extensiva por nós assim identificada. Ela tem múltiplas histórias e aventuras próprias à constituição de sua singularidade corpórea (os processos de formação do planeta, os movimentos das placas tectônicas, as águas e os ventos que durante milhões de anos ela agenciou para ir paulatinamente esculpindo intensivamente seu ser, além da mera forma extensiva). $\mathrm{O}$ encontro com vegetais e animais que a rolaram, que a jogaram, que ela revidou com sua dureza etc., em encontros contingenciais de múltiplos corpos que se afetam, se atravessam, se tensionam.

São múltiplas histórias que aconteceram enquanto coetaneidade no aqui dessa pedra, sua espacialidade múltipla como expressão e mistério de toda uma luta por sobreviver e durar no mundo. Mas só vamos dando conta desse devir rocha em nós no encontro com as imagens presentes nas palavras da poesia. No poema ela, a pedra, toma uma forma espacial prenhe de sentidos, passa a ser uma personagem, uma figura estética que deixa de ser algo restrito a exterioridade de um espaço extensivo e passa a se intensificar, se dobra em nós e aponta outros territórios de possibilidades de vida, desterritorializando o que nosso pensar até então tinha restringido enquanto forma e função mineral. A arte poética, assim, nos coloca em deriva de nós mesmos, rasura nossas ideias prontas e acabadas, faz a gente devir outra coisa, força-nos a sentir diferente, a nos diferenciar do que entendemos ser nós mesmos enquanto humanos, demasiados humanos.

É como se o sentido de paisagem deixasse de ser algo humano, puro devir ausência do homem, com suas forças percpetuais e afectuais, mas por isso mesmo nos afetando humanamente. 
É o enigma (frequentemente comentado) de Cézanne: "o homem ausente, mas inteiro na paisagem". Os personagens não podem existir, e o autor só pode cria-los porque eles não percebem, mas entraram na paisagem e fazem eles mesmos parte do composto de sensações [...]. Os afectos são precisamente estes devires não humanos do homem, como os perceptos ... são as paisagens hão humanas da natureza. "Há um minuto do mundo que passa", não o conservaremos sem "nos transformarmos nele", diz Cézanne. Não estamos no mundo, tornamo-nos mundo, tornamo-nos com o mundo [...]. Tudo é visão, devir. Tornamo-nos universo. Devires animal, vegetal, molecular, devir zero (DELEUZE; GUATTARI, 2010, p. 219-220).

Que instigante Geografia temos a partir dessa abordagem! Devir mundo, ou seja, não restrito a um ser especial que pensa como o mundo deve se comportar, mas sentir com o mundo, tornar-se mundo. Só a arte tem essa capacidade de nos afetar. Aí a linguagem geográfica pode ser um agenciamento de outros possíveis para o homem melhor se entender não somente sobre o mundo, tendo esse como um espaço extensivo e externo ao corpo humano, mas para melhor se localizar e se orientarcomo/com o mundo, tendo esse como forças intensivas a se dobrarem na interioridade dos corpos/pensamentos/sensações. Espaço, assim, acontecendo na imanência da vida na contingência do encontro dos corpos (pedra-pensamento-paisagem-sensação-homem-coisa-devir etc.)

\section{CONCLUSÃO}

Como resultado dos trabalhos apresentados no GT Geografias, Imagens e Literatura: Interlocuções Possíveis, aqui analisados, podemos destacar que as interlocuções se efetivaram a partir das diferenças que podem ser assim pontuadas:

a. As diferenças entre as linguagens científica e artísticas, as quais, por buscarem processos distintos de expressar os sentidos do/no mundo, permitem que o mundo nunca seja fixado numa definição acabada e generalizante, pelo contrário, que este seja constante processo e desafio de criar sempre e sempre, num contínuo movimento de novos e múltiplos sentidos de leitura e entendimento (CHAVEIRO, 2011). A potência da linguagem artística se encontra em seu plano de composição, em seus monumentos de sensações que afetam os corpos, que instigam a criar novos pensamentos do/no mundo, novas palavras e imagens que, no caso do discurso científico da Geografia, aponta para novos sentidos de como pensar, imagear e escrever o mundo em sua dinâmica espacial (OLIVEIRA JR., 2009).

b. As diferenças entre literatura e imagem como forma de desafiar o enquadramento das forças transgressoras da palavra e da imagem, enquadramento instaurado pelos processos de subjetivação e estriamento espacial na sociedade pautada nos 
determinantes do grande mercado econômico (DELEUZE, GUATTARI, 2010).É necessário usar da força poética da palavra, elemento chave na linguagem literária, para rasurar os limites que enclausuram o pensar nos significados dos significantes da dinâmica espacial do mundo (LARROSA; SKLIAR, 2011). Ao mesmo tempo, no contato entre essas linguagens distintas, forçar as imagens para não se consolidarem em clichês que amorteçam o sentir e o pensar na mera reprodução de fatos em si (FERRAZ, 2015), daí serem elas, as imagens, forças que não se restringem a serem ilustrações do pensamento, do conhecimento científico, não se limitam a iludir com a crença de serem representações da realidade espacial (GIRARDI, 2013).

c. As diferenças entre perspectivas teóricas e de referenciais de entendimento de ciência geográfica, de maneira que a busca por novas metodologias e temas de pesquisa não seja um fator inibidor para se pensar o desafio que está além do pensável como ciência e práticas geográficas atualmente consolidadas (SUZUKI, 2010). O novo não se reduz a ser novidade, a ser inovação, mas é o virtual como real atualizado, o que constrange, rasura, deriva e instaura outros possíveis - tornar visível as forças não visíveis (DELEUZE, GUATTARI, 2010).No encontro dessas diferenças teóricas e metodológicas é que, talvez, possamos construir um conhecimento que não se restrinja mais a tentar resolver os limites da prática/discurso cientifico institucionalizado, mas sim que coloque em fuga essa concepção de ciência e afirme a possibilidade de outras imagens e pensamentos científicos, de que o método não seja a camisa de força que defina o como se fazer ciência, mas que seja iluminado por um fazer criativo, artisticamente dinâmico e múltiplo, de uma Geografia que se entenda como prática espacial múltipla, diferenciadora e em aberto (MASSEY, 2009).

Dessas diferenças, que se atravessam e se afetam mutuamente, podemos traçar linhas possíveis, linhas de fuga imbricadas a linhas flexíveis e duras, linhas que desterritorializam o já estabelecido, mas que provocam novas reterritorializações de possíveis. Temos, assim, a constituição de um movimento geográfico, de uma "geografia nômade" (aqui em minúscula) que de sua imaterialidade se atualiza em possíveis formas de localização e orientação dos corpos no/como mundo. A força poética da Geografia é a força geográfica da poesia que vê e anuncia uma ordem nova para as coisas do mundo.

[...] anuncia uma ordem nova para as coisas do mundo (uma geografia) que é e não é deste mundo (é imaterial, é o invisível que no visível se revela), e por isso é sempre algo de diferido, da ordem do desejo (por vir). Nesse por vir [...] limita-se a agir [...] a ver e ouvir o mundo vivo (o mundo do Vivo), num mundo que perdeu essas faculdades e já só sobre-vive, ou corre sem saber para onde vai (BARRENTO, 2014, p. 18-19). 
Agenciando a força geográfica dessa imaterialidade poética presente na literatura e nas imagens artísticas (LLANSOL, 2000), temos a possibilidade da poética imagético/literária se dobrar em linguagens geográficas, de sua imaterial localização nos espaços artísticos para, num movimento de redobras, acontecer no mundo enquantoespaço/vida, ou seja, se materializar como corpos espaciais que busquem melhor saber onde ir, por saberemse localizar em meio a esse movimento constante de dobras e redobras.

Vamos, assim,destacando que a linguagem geográfica não se restringe a ser um mero reproduzir de referenciais cientificistas, palavras devidamente articuladas a tentar ordenar o mundo pela lógica da razão instrumental. A linguagem geográfica é essa interação entre a palavra que transcende seus limites lógico gramaticais, se engravida da palavra poética e se dobra no encontro com as linguagens imagéticas (FERRAZ, 2015), dessa maneira, é mutuamente atravessada de novos sentidos e pensamentos espaciais. Essa é uma questão fundamental que resulta e mobiliza as discussões do GT e do ponto de vistados avanços ou rasuras nos esquemas com que usualmente a Geografia se coloca como conhecimento institucionalizado.

As imagens, portanto, não são passíveis de serem localizadas num contexto lógico regido pela ordem gramatical da palavra, do conceito que estabelece uma identidade fixa e o localexato dos fenômenos sobre uma extensão espacial, pois elas (as imagens) são fluídas, instauram devires minoritários no que se tem já consolidado como concepção de Geografia (OLIVEIRA JR., 2009). As imagens cobram outras formas de pensar, outras formas de experimentar os processos de localização e orientação, não mais como representação de um corpo, de sua localização numa dada extensão do território, mas de como os corpos constituem o mundo imageticamente, como força poética e desestabilizadora, iminente a espacialidade da vida.

Isso que a imagem dá a pensar se situa talvez lá, nesta imanência que não pertence a ninguém, alguma coisa que se tem diante (em todos os sentidos da palavra): nem aqui nem em outro lugar, nem presente nem ausente, mas iminente [...] as imagens não saberiam propriamente ser localizadas nem aqui nem lá, mas constituem precisamente esse entre que mantém a relação. Como tais, as imagens requerem uma outra forma de pensar que suspenderia suas certezas (ALLOA, 2015, p. 16).

As imagens, portanto, possuem uma força poética capaz de desestabilizar os clichês visuais com que se usualmente tentam reduzir a potencialidade das imagens a mera ilustração da ordem da palavra, como ocorre normalmente com as fotografias, gráficos, mapas e demais imagens presentes nos materiais didáticos de Geografia, ou seja, apenas ilustram ou reforçam por repetição do óbvio um conteúdo definido e apresentado pelo encadeamento das palavras. Mas a potencialidade subversiva das imagens em seu plano 
estético é justamente rasurar esses clichês, derivando do que aparece como certo e definitivo, abrindo o pensamento para outras sensações e possibilidades de leitura e entendimento do mundo.

Temos assim, para a Geografia, nesse encontro com a imagem artística, a possibilidade das imagens instigarem outras sensações e pensamentos espaciais, ao invés de continuar presa a modelos representacionais que visam representar idealmente o mundo, seja por modelos cartográficos, seja por filmes, fotografias etc., ou seja, imagens a criarem novos sentidos cartográficos, capazes de instigar outras perspectivas e formas espaciais (GIRARDI, 2013), fazendo as imagens não se reduzirem a clichês ilustrativos do saber já estabelecido como verdade pelas palavras do discurso científico, mas instaurando forças geográficas pelas e nas imagens.

Essas derivas minoritárias potencializadas no encontro do discurso científico da Geografia com o artístico das imagens também reverbera nos encontros com a ordem poética presente na criação literária, seja em romances, contos, poesias, etc. De um lado, a ordem da palavra com que se articula a construção da obra literária possui também essa dupla capacidade de, como arte, poder ser empregada para reforçar valores e ideias já consolidadas, como os clichês imagéticos, mas por ser artístico, pode subverter a ordem das coisas e abrir para outras possibilidades. Deixemos o crítico e poeta Affonso Romano Sant’anna falar, a partir de uma grande escritora brasileira, sobre esse perigo e poder da palavra.

\footnotetext{
Uma personagem de Clarice Lispector indaga: "Você sabe que a pessoa pode encalhar numa palavra e perder anos de vida?" Vejam só, encalhar numa palavra. A pessoa vai no seu barquinho vida adentro e, de repente, encalha numa palavra. Pode ser 'marxismo', 'Deus', 'pai,' 'vanguarda,' 'revolução,' 'Paris,' 'aposentadoria,' 'desemprego,' 'reforma agrária,' 'corrupção', 'subdesenvolvimento' [...]. Escritor, no entanto, não é aquele que acumula palavras obscuras num museu egoísta ou cofre de erudição, mas quem as troca na bela moeda da emoção. [...]. Com as palavras, a gente tem de tomar cuidado, pois no primeiro encontro nos libertam, depois nos aprisionam [...]. Viver também é a arte de lidar com as palavras ... "são caminhos para encontrar coisas perdidas” (SANT’ANNA; COLASANTI. 2013, p. 191-193).
}

A palavra, portanto, é um signo que pode bloquear o pensar/agir quando toma ares metafísicos transcendentes, quando o pensamento a toma como a representação de um significante, como busca de uma essência verdadeira a ser fixada como normatizadora da vida. Algo que veda a percepção para o entorno, para a dinâmica do viver e ofusca a mente, se colocando como busca pela essência última do que aquilo quer dizer, um conceito monstro a atormentar nossos desejos e pensamentos. Contudo, quando o pensamento a coloca como um signo a mais, como um componente da comunicação e não como uma expressão a representar a verdade em si de algo, a palavra torna-se maleável, passível de ser dobrada em outras coisas, capaz de emocionar e de afetar. Temos aí a força da palavra 
poética, da palavra artística. Palavra capaz de romper as amarras de um pensar doentio de racionalismo e criar linhas de liberdade possíveis.

Quando isso reverbera no discurso científico da Geografia, podemos perceber que a concepção de objetividade e de verdade a ser atingida pelo rigor e precisão de determinadas palavras, estas acabam bloqueando o pensar geográfico para outras possibilidades do sentir/viver a dinâmica espacial da vida. Ficamos presos em desvendar a verdade última e definitiva do que vem a ser "território", "região", "paisagem”, "espaço", "Geografia Física/ Geografia humana" etc. Ao invés de ficarmos bloqueados pelas palavras, de ficarmos rodando e rodando atrás de saber "o que são essas palavras", seria mais instigante ouvir o poeta e pensarmos "o que podem essas palavras".

E essa força advém de poder enunciativo das mesmas, de enunciar um povo porvir, de enunciar outras possibilidades de se viver (DELEUZE; PARNET, 2004), de enunciar outras geografias possíveis, as que não se restringem a conhecimento sobre a extensividade do espaço, mas que se dobra pela intensividade afetiva dos corpos, provocando novos acontecimentos espaciais; uma geografia singular na qual novas paisagens, não mais exteriores a quem as percebe, mas imanentes a quem as vivencia, de maneira que todas as sensações, pensamentos e imagens possam acontecer, atravessar e se localizar.

Trata-se de construir um espaço singular, um 'plano de imanência ou de consistência' ... que torne possível tal sentir [...]. A visão da paisagem exterior mistura-se com as sensações interiores e criam uma nova entidade, um híbrido sensitivo de interior e exterior[...]. Compreende-se que a escrita poética tem o valor de uma ação capaz de transformar o modo de sentir, é porque já se tinha formado um plano de imanência, virtual ou interior, em que o movimento da escrita desposava totalmente o movimento do sentir ... ou seja, a escrita não descreve ou designa ou mesmo exprime, o sentir, mas o seu movimento é o movimento do sentir [...]. É pela imanência, na imanência, que as palavras agem, revertendo o interior no exterior, constituindo uma superfície sensitiva onde todas as imagens e todas as sensações circulam (GIL, 2000, p. 117-131).

Essas palavras do filósofo português são cruciais para nosso entendimento do que pode uma palavra artística, em especial no encontro com as imagens e sensações no acontecer espacial dos corpos. Com a palavra poética podemos pensar a possibilidade de nós, geógrafos, construirmos "um espaço singular", que torna possível sermos afetados pelos corpos que ali se encontram, fazendo da "paisagem exterior" forças que se intensificam nos corpos afetados.

Passamos, assim, a mudar nossa forma de sentir, fazendo do espaço geográfico algo que só se realiza nessa relação exterior/interior, de uma racionalidade que acontece enquanto e nas sensações dos encontros, um acontecer contingencial que a linguagem científica deve buscar atualizar em possíveis formas outras de orientação e localização, não restritas a 
pura exterioridade extensiva da objetividade analítica, mas também não limitada apenas a interioridade intensiva das sensações subjetivas. Outras imagens espaciais daí reverberam em nosso pensar/sentir/viver o mundo pela perspectiva da leitura geográfica.

De tudo que lemos, ouvimos, debatemos, analisamos e buscamos dialogar no interior do GT, assim como após a realização do mesmo, percebemos que as tensões, distâncias e mútuos afetamentos que aconteceram e ainda acontecem expressam o acerto de estabelecer uma instância propiciadora desses encontros entre a palavra de ordem científica do discurso geográfico com as palavras desestabilizadoras da poética literária, que acabaram atravessadas e atravessando a diversidade de linguagens imagéticas, dobrando os sentidos de cada um desses planos de produção de conhecimento.

Instaurou-se a possibilidade de construir novos pensamentos, sejam imagéticos, sejam literários, sejam científicos, mas todos funcionando como intercessores de novos sentidos e imagens espaciais, de uma outra Geografia possível. Diante disso, evidenciouse que o trabalho geográfico faz uso de mecanismos simbólicos e linguísticos, bem como imagéticos, imaginativos e estéticos, próprios do labor artístico, que reverberam em novas sensibilidades e pensamentos espaciais, potencializando outras narrativas geográficas, objetivando a compreensão mais dinâmica e diferenciada das relações sociais em seus referenciais espaço-temporais.

\section{REFERÊNCIAS}

1. ALLOA, Emmanuel. Entre a transparência e a opacidade - o que a imagem dá a pensar. In: ALLOA, Emmanuel (Org.). Pensar a imagem. Belo Horizonte: Autêntica, 2015, p. 07-19.

2. BARRENTO, João. Geografia imaterial - três ensaios sobre a poesia. Lisboa: Documenta, 2014.

3. BARROS, Manoel. Tratado geral das grandezas do ínfimo. Rio de Janeiro: Record, 2005.

4. CHAVEIRO, Eguimar F.; FELÍCIO, Goiamérico. Sentidos e desafios da literatura nas sociedades da imagem. Aphonline. Trindade (GO),v.1, n.1, p.4-14, jan./jun. 2011. http://www.aphonsiano. edu.br/revista/edicao01/ARTIGO_2..pdf. Acessado em 29/12/2015.

5. DELEUZE, Gilles; GUATTARI, Félix. O que é Filosofia? Rio de Janeiro: Ed. 34, 2010.

6. DELEUZE, Gilles; PARNET, Claire. Diálogos. Lisboa: Relógio D’Água, 2004.

7. FERRAZ, C. B. O. Nietzsche Corpo/Espaço: do cinema para as geografias. In:AZEVEDO, A. F., RAMIREZ, R. C.; OLIVEIRA JR., W. M. (orgs.). Intervalo I: entre geografias e cinemas. Braga (PT): UMDGEO - Departamento de Geografia, Universidade do Minho, 2015, p. 6596. Livro eletrônico: http://hdl.handle.net/1822/35539 
8. GIL, José. Diferença e negação na poesia de Fernando Pessoa. Rio de Janeiro: Relume Dumará, 2000.

9. GIRARDI, Gisele. Política e potência das imagens cartográficas na geografia. In: CAZETTA, Valéria; OLIVEIRA JR., Wenceslao M. (orgs.). Grafias do espaço - imagens da educação geográfica contemporânea. Campinas (SP): Editora Alínea, 2013, p. 69-86.

10. LARROSA, Jorge; SKLIAR, Carlos (orgs.). Habitantes de Babel - políticas e poéticas da diferença. Belo Horizonte: Autêntica Editora, 2011.

11. LAZZARATO, Maurizio. Signos, máquinas, subjetividades. São Paulo: Edições SESC/N-1 Edições, 2014.

12. LLANSOL, Maria G. Onde vais, drama poesia? Lisboa: Relógio d’Água, 2000.

13. MASSEY, D. Pelo Espaço: uma nova política da espacialidade. 2. ed. Rio de Janeiro: Bertrand Brasil, 2009.

14. OLIVEIRA, Jr. Wenceslao M. Grafar o espaço, educar os olhos. Rumo a geografias menores. Pro-Posições. Campinas, v. 20, n. 3 (60), p. 17-28, set./dez., 2009.

15. PELBART, Peter P. Como viver só? In: BIENAL de São Paulo $\left(27^{\mathrm{a}}, 2006\right) .27^{\mathrm{a}}$ Bienal de São Paulo: Seminários. Curadoria Geral Lisette Lagnado. Rio de Janeiro: Cabrobó, 2008.

16. SANT’ANNA, Affonso R.; COLASANTI, Marina. Com Clarice. São Paulo: Editora UNESP, 2013.

17. SUZUKI, Júlio C. O poeta, a cidade e o esfacelamento do indivíduo na modernidade: uma leitura de "A rosa do povo". In: MARANDOLA JR., Eduardo; GRATÃO, Lúcia H. B. (Orgs.). Geografia e Literatura - ensaios sobre geograficidade, poética e imaginação. Londrina (PR): EDUEL, 2010, p. 243-256.

Artigo recebido em 25 de março de 2016.

Artigo aceito em 25 de abril de 2016. 